\title{
PENDIDIKAN BIOLOGI BERBASIS IMTAQ SEBAGAI USAHA PEMBENTUKAN KARAKTER BANGSA
}

\author{
Milya Sari \\ Dosen Fakultas Tarbiyah IAIN Imam Bonjol Padang \\ Korespondensi: Jl. Green Bariang Indah III/E Anduring Padang \\ e.mail: milyasari.iain@gmail.com
}

\begin{abstract}
Indonesia's education system hasn't been able to reflect the learners and educational output character. One cause is the paradigm the teacher who assumes coaching Morals as the character formation of students in the school as a teacher of religious education task. Coaching these characters could be done by science teachers particularly biology, according to the purpose of the first biological subjects. Biology teacher responsible for teaching the values of Islam (imtaq) in the material he teaches. To cultivate ketaqwaannya, then all learner activities; think, feel, behave, and act responsibly (BMB3) will be based on the values ketaqwaan. This will form the learners character illustrated in appearance everyday
\end{abstract}

Kata kunci: Pendidikan biologi. Pendidikan karakter, Imtaq dan iptek

\section{PENDAHULUAN}

? lujuan yang paling mendasar dari pendidikan adalah untuk membuat seseorang menjadi "good and smart". Manusia yang terdidik seharusnya menjadi orang bijak, yaitu yang dapat menggunakan ilmunya untuk hal-hal yang baik (beramal shaleh), dan dapat hidup secara bijak dalam seluruh aspek kehidupan berkeluarga, bertetangga, bermasyarakat, dan bernegara. Karenanya, sebuah sistem pendidikan yang berhasil adalah yang dapat membentuk manusia-manusia berkarakter yang sangat diperlukan dalam mewujudkan sebuah Negara kebangsaan yang terhormat. Hal ini sesuai dengan UU No 20 Tahun 2003 Tentang Sistem Pendidikan Nasional pada Pasal 3, yang menyebutkan bahwa: "Pendidikan nasional berfungsi mengembangkan kemampuan dan membentuk karakter serta peradaban bangsa yang bermartabat dalam rangka mencerdaskan kehidupan bangsa. Pendidikan nasional bertujuan untuk berkembangnya potensi peserta didik agar menjadi manusia yang beriman dan bertakwa kepada Tuhan Yang Maha Esa, berakhlak mulia, sehat, berilmu, cakap, kreatif, mandiri, dan menjadi warga negara yang demokratis serta bertanggung jawab."

Sesuai dengan tujuan pendidikan nasional tersebut, dimensi iman dan taqwa (imtaq) dan berakhlak mulia merupakan bagian yang terpadu dari tujuan pendidikan nasional. Artinya, untuk menjadikan manusia yang berkarakter; cinta damai, jujur, bertanggung jawab dan baik akhlaknya, merupakan tugas semua pihak bukan hanya tugas dari bidang kajian atau kegiatan tertentu. Dengan demikian pendidikan sebagai suatu system yang terpadu harus secara sistematis diarahkan untuk membentuk manusia-manusia yang berkarakter. 
Dewasa ini ada sesuatu yang memprihatinkan dengan dunia pendidikan di Indonesia. Proses pendidikan ternyata belum berhasil membangun manusia Indonesia yang berkarakter. Banyak yang menyebut bahwa pendidikan telah gagal membangun karakter. Banyak lulusan sekolah/madrasah dan sarjana yang pandai dalam menjawab soal ujian, berotak cerdas, tetapi mentalnya lemah, penakut, dan perilakunya tidak terpuji. Kebijakan pendidikan di Indonesia juga lebih mementingkan aspek kecerdasan otak, dan hanya baru-baru ini saja pentingnya pendidikan budi pekerti. Ada yang mengatakan bahwa kurikulum pendidikan di Indonesia dibuat hanya cocok untuk diberikan pada 10-20 persen otak-otak terbaik. Artinya sebagian besar anak sekolah/madrasah (80-90 persen) tidak dapat mengikuti kurikulum pelajaran di sekolah/madrasah. Akibatnya sejak usia dini, sebagian besar anak-anak akan merasa "bodoh" karena kesulitan menyesuaikan dengan kurikulum yang ada. Ditambah lagi dengan adanya sistem ranking yang telah "memvonis" anakanak yang tidak masuk "10 besar", sebagai anak yang kurang pandai. Sistem seperti ini tentunya berpengaruh negatif terhadap usaha membangun karakter, dimana sejak dini anak-anak justru sudah "dibunuh" rasa percaya dirinya. Rasa tidak mampu yang berkepanjangan yang akan membentuk pribadi yang tidak percaya diri, akan menimbulkan stress berkepanjangan. Pada usia remaja biasanya keadaan ini akan mendorong remaja berperilaku negatif.

Dari banyak problem mengenai masalah pendidikan, tulisan ini hanya mengkaji salah satu aspek saja, yaitu aspek moralitas (akhlak) yang disebut juga karakter (catatan Perkuliahan Teori Pendidikan tanggal 5/10/2011 dengan Prof. Prayitno) yang secara spesifik menyoroti potret peserta didik atau bahkan output pendidikan di Indonesia yang akhir-akhir mengalami degradasi moral. Realitas ini berangkat dari permasalahan mendasar, 1) mengapa peserta didik dan output pendidikan di Indonesia masih banyak yang belum mencerminkan karakter (kepribadian yang berakhlak mulia)? dan 2) bagaimana tanggungjawab dan solusi institusi pendidikan (sekolah, masyarakat, dan keluarga) atas persoalan tersebut?

Asumsinya, kegagalan pendidikan di Indonesia yang belum mampu mencerminkan peserta didik dan output pendidikan yang berkarakter (berakhlak mulia) sebagaimana pertanyaan di atas disebabkan adanya kekeliruan dalam tiga hal, 1) berkaitan dengan tolok ukur yang dipakai dalam menilai keberhasilan peserta didik, 2) intensitas partisipasi masyarakat dan orang tua (keluarga), dan 3) paradigma guru atau dosen dalam proses pembelajaran.

Berkaitan dengan aspek tolok ukur yang dipakai dalam menilai keberhasilan peserta didik. Selama ini guru atau dosen dalam menentukan tolok ukur keberhasilan anak didik dalam proses pembelajaran banyak yang hanya menitikberatkan pada aspek kognitif saja, sementara aspek yang lebih substansial yakni aspek afektif dan psikomotorik masih dikesampingkan, sehingga ada anak didik yang pintar, akan tetapi sikap dan perilakunya tidak menunjukkan perilaku yang terpuji.

Partisipasi masyarakat dan orang tua juga merupakan salah satu pihak yang dapat mendukung dan menetukan keberhasilan pendidikan formal dalam mengantarkan anak didik yang berakhlak mulia. Selama ini memang masih banyak mayarakat yang kurang peduli dengan sikap dan perilaku para pelajar atau mahasiswa. Mereka punya pendirian, bahwa sekolah sudah diserahi tanggungjawab untuk mendidiknya, dan juga 
kalau diantara mengetahui kalangan pelajar berbuat menyimpang, mereka acuh tak acuh dengan alasan bukan anaknya. Berkaitan dengan kegagalan pendidikan di Indonesia dalam melahirkan peserta didik dan output pendidikan yang karakter, tulisan ini fokus kepada paradigma guru atau dosen dalam proses pembelajaran dan bagaimana pendidikan karakter melalui pembelajaran biologi berbasis imtaq.

\section{PARADIGMA GURU}

Kenyataan yang sering teramati, bahwa paradigma guru dalam perannya sebagai pendidik hanya mengajar bukan mendidik, sehingga yang yang terjadi adalah kalau sudah selesai mengajar, berarti sudah selesai pula tugasnya. Kalau kenyataannya seperti itu, berarti tugas guru atau dosen hanya memindahkan ilmu pengetahuan yang dimiliki kepada anak didiknya (transfer of knowledge), belum melaksanakan tugas dan peran guru yang sebenarnya yaitu menanamkan nilai-nilai moral (akhlak) melalui keteladanan sikap dan perilakunya (transfer of value). Padahal dalam pelaksanaannya keduanya harus dipadukan secara total, tidak parsial. Dengan demikian, guru atau dosen dituntut mampu mencerminkan perilaku yang terpuji. Dan, ini memang tanggungjawab berat seorang pendidik karena ia merupakan cermin kehidupan bagi anak didiknya.

Sehubungan dengan perilaku guru atau dosen merupakan contoh teladan dari peserta didiknya, Prayitno (2009) secara khusus menyatakan keteladanan merupakan bagian dari pilar kewibawaan dalam proses pendidikan. Keteladanan merupakan puncak penampilan pendidik terhadap peserta didik. Seluruh penampilan pendidik yang didasarkan pada penerimaan dan pengakuan, kasih sayang dan kelembutan, dalam bentuk penguatan dan TTM (tindakan Tegas
Mendidk), yang seluruhnya positif dan normatif itu, diharapkan dapat diterima dan bahkan ditiru oleh peserta didik. Satu hal yang menjadi kunci bagi terlaksananya keteladanan adalah ketaatasan (konsistensi) penampilan pendidik dengan materi yang patut diteladani peserta didik.

Selama ini pembinaan Akhlak sebagai pembentukan karakter siswa di sekolah dianggap sebagai tugas pendidikan agama. Bagi siswa yang beragama islam tugas itu hanya menjadi tanggungjawab guru Pendidikan Agama Islam (PAI) saja. Mempercayakan pendidikan karakter siswa hanya kepada satu mata pelajaran mengandung kelemahan. Baik dari segi hakikat pendidikan nasional sebagai suatu sistem maupun hakekat proses pendidikan yang ideal, yaitu yang mampu mengembangkan semua dimensi kepribadian peserta didik secara utuh seperti yang dinyatakan dalam GBHN dan UU Sisdiknas (Dedi Supriadi, 2004). Sejalan dengan hal ini Prayitno (2009) menyatakan bahwa tujuan pendidikan itu tidak lain adalah pengembangan HMM (Harkat Martabat Manusia). Kegiatan pembelajaran yang teraktualisasi dalam proses pembelajaran merupakan dasar bagi pemuliaan atas kemanusiaan manusia.

Sebagai upaya untuk menjawab permasalahan tersebut, perlu adanya paradigma baru dari guru tentang pendidikan karakter (akhlak) di sekolah/madrasah. Pembinaan karakter ini bisa dilakukan oleh guru IPA khususnya biologi, dengan mengintegrasikan nilainilai karakter dalam kegiatan pembelajaran. IPA (sains) dan teknologi sebagai penerapannya mempunyai implikasi sosial dan moral yang sangat luas, untuk itu perlu memberikan nilai pada bidang ini. Nilai yang dimaksud dapat berupa nilai budaya dan nilai etikamoral, termasuk nilai moral keagamaan. Diyakini sains dan teknologi tidak lagi bebas nilai, tetapi justru terikat nilai 
bahkan berkaitan dengan budaya. Oleh sebab itu perlu dikembangkan pendidikan sains yang berbasis nilai dengan cara mengintegrasikan iptek dan imtag, sehingga peserta didiknya tidak hanya menguasai iptek saja tetapi juga berimtaq. Dengan imtaq yang dimilikinya diharapkan peserta didik punya karakter yaitu, orang yang dapat menggunakan ilmunya untuk hal-hal yang baik (beramal shaleh), dan dapat hidup secara bijak dalam seluruh aspek kehidupan berkeluarga, bertetangga, bermasyarakat, dan bernegara.

\section{PENDIDIKAN KARAKTER}

Pendidikan adalah proses perubahan perilaku yang sesuai dengan nilainilai budaya bangsa, agama dan budaya lokal serta pengembangan potensi peserta didik secara normal. Sedangkan karakter dalam pandangan umum adalah watak, tabiat, akhlak, atau kepribadian seseorang yang terbentuk dari hasil internalisasi berbagai kebijakan yang diyakini dan digunakan sebagai landasan untuk cara pandang, berpikir, bersikap, bersikap, berperilaku, dan bertindak. Pendidikan karakter merupakan usaha menanamkan kebiasaan-kebiasaan yang baik, sehingga peserta didik mampu bersikap dan bertindak berdasarkan nilainilai yang telah menjadi kepribadiannya sehari-hari. Islam juga mengajarkan nilai-nilai karakter ini, nilai-nilai yang terdapat dalam Al-Qur'an berkaitan dengan Akhlak terpuji (yang harus dilakukan) dan akhlak tercela (yang harus dihindari). Akhlak terpuji antara lain: perlakuakn yang baik, berlomba dalam mengerjakan kebaikan, ucapan yang baik, muka yang berseri. Sedangkan akhlak tercela antara lain: budi pekerti yang jelek, pendapat yang tegesa-gesa, pengecut, perkataan yang tidak sesuai dengan perkataan.
Berdasarkan hal itu pendidikan Karakter perlu dikembangkan di sekolah/madrasah. Sebagai upaya untuk meningkatkan kesesuaian dan mutu pendidikan karakter, Kementerian Pendidikan Nasional mengembangkan grand design pendidikan karakter untuk setiap jalur, jenjang, dan jenis satuan pendidikan. Grand design menjadi rujukan konseptual dan operasional pengembangan, pelaksanaan, dan penilaian pada setiap jalur dan jenjang pendidikan. Adapun acuan konfigurasi karakter dalam konteks totalitas proses psikologis dan sosial-kultural tersebut dikelompokan sebagaimana uraian berikut: (1) Olah Hati (Spiritual and emotional development), Olah hati bermuara pada pengelolaan spiritual dan emosional, (2) Olah Pikir (intellectual development), Olah pikir bermuara pada pengelolaan intelektual, (3) Olah Raga dan Kinestetik (Physical and kinestetic development), Olah raga bermuara pada pengelolaan fisik, dan (4) Olah Rasa dan Karsa (Affective and Creativity development), Olah rasa bermuara pada pengelolaan kreativitas

Thomas Lickona dalam bukunya yang berjudul "Eleven Principles Of Effective Character Education" khusus mendiskusikan bagaimana seharusnya, melaksanakan pendidikan karakter di sekolah/madrasah yang dikutip dari beberapa pakar pendidikan. Prinsip-prinsip ini secara inplisit dan eksplisit sudah mewakili poin-poin yang sudah digariskan dalam grand design Kemendiknas. Secara ringkas prinsip-prinsip yang dapat menentukan kesuksesan pendidikan karakter sebagai berikut; (1) Pendidikan karakter harus mengandung nilai-nilai yang dapat membentuk " good character". (2) Karakter harus didefinisikan secara menyeluruh yang termasuk aspek "thinking, feeling and action". (3) Pendidikan karakter yang efektif memer- 
lukan pendekatan komprehensif dan terfokus dari aspek guru sebagai "role model", disiplin sekolah, kurikulum, proses pembelajaran, manajemen kelas dan sekolah, integrasi materi karakter dalam seluruh aspek kehidupan kelas, kerjasama orang tua, masyarakat dan sebagainya. (4) Sekolah harus menjadi model "masyarakat yang damai dan harmonis". (5) Untuk mengembangkan karakter, para murid memerlukan kesempatan untuk mempraktekkannya, (6) Pendidikan karakter yang efektif harus mengikutsertakan materi kurikulum yang berarti bagi kehidupan anak atau berbasis kompetensi (life skill) sehingga anak merasa mampu menghadapi dan memecahkan masalah kehidupan. (7) Pendidikan karakter harus membangkitkan motivasi internal dari diri anak. (8) Seluruh staf sekolah harus terlibat dalam pendidikan karakter. Peran kepala sekolah sangat besar dalam memobilisasi staf untuk menjadi bagian dari proses pendidikan karakter. (9) Pendidikan karakter di sekolah memerlukan kepemimpinan moral dari berbagai pihak; pimpinan, staf dan para guru. (10) Sekolah harus bekerja sama dengan orang tua murid dan masyarakat sekitarnya, (11) Harus ada evaluasi berkala mengenai keberhasilan pendidikan karakter di sekolah.

Sehubungan dengan sebelas hal tersebut, Lickona (dalam Lufri \& Festiyet, 2011) menyatakan strategi pelaksanaan pendidikan karakter lebih terpusat kepada guru dan lingkungan sekolah. Untuk guru, hal yang harus dilakukan dalam kelas adalah: (1) bertindak sebagai pemberi perhatian, model dan mentor. (2) menciptakan kelas menjadi masyarakat yang bermoral, (3) menerapkan disiplin moral, dengan menerapkan peraturan kelas beserta perangkat penguatannya seperti hadiah atau hukuman, (4) menciptakan lingkungan yang demokratis di dalam kelas, dengan cara mengikut sertakan peserta didik dalam berbagai pengambilan keputusan, (5) mengajarkan berbagai nilai moral lewat kurikulum, dengan menggunakan materi pelajaran sebagai alat menelaah berbagai dilema moral, (6) mengajak peserta didik belajar bekerja sama, (7) mengembangkan etos kerja, dengan mendorong peserta didik memiliki tanggung jawab akademik, dan menghargai nilai bekerja dan belajar, (8) mengajak peserta didik mengadakan perenungan moral, melalui bacaan, menulis, diskusi, latihan mengambil keputusan, dan debat, (9) mengajarkan penyelesaian konflik. Sedangkan di luar kelas, lingkungan sekolah diharapkan untuk : (1) mengembangkan sikap saling memperhatikan di luar kelas, dengan menyediakan model perilaku, dan mengadakan pelayanan sosial kepada masyarakat, (2) menciptakan budaya moral di lingkungan sekolah, (3) mengikutsertakan pihak orang tua dan masyarakat serta kalangan bisnis dalam memperkuat nilai-nilai yang diajarkan oleh sekolah.

Prayitno (2011) menyatakan karakter dibentuk melalui pengembangan unsur-unsur harkat dan martabat manusia (HMM) yang secara keseluruhan berkesesuaian dengan nilai-nilai luhur pancasila. HMM meliputi tiga komponen yaitu hakikat manusia, dimensi kemanusiaan, dan pancadaya kemanusiaan.

a. Hakikat manusia, meliputi lima unsur, yaitu bahwa manusia diciptakan sebagai mahkluk yang beriman dan bertaqwa, paling sempurna, paling tinggi derajatnya, khalifah dimuka bumi, dan penyandang HAM. Pembentukan karakter sepenuhnya mengacu kepada kelima unsur hakikat manusia ini.

b. Dimensi kemanusiaan, meliputi lima dimensi, yaitu dimensi kefitrahan, dimensi keindividualan, dimensi kesosialan, dimensi kesusilaan, dan dimensi keberagaman. Kelima dimensi ini men- 
cerminkan karakter individu dalam kehidupan sehari-hari.

c. Pancadaya kemanusiaan, meliputi lima potensi dasar, yaitu daya taqwa, daya cipta, daya rasa, daya karsa dan daya karya. Melalui pengembangan seluruh unsur pancadaya inilah pribadi berkarakter dibangun.

Upaya untuk mewujudkan pendidikan karakter adalah dengan mengintegrasikan nilai-nilai keimanan dan ketaqwaan (imtaq) ke dalam substansi pembelajaran. Penanaman nilai-nilai imtaq merupakan bagian dari HMM. Prayitno (2009) mengemukakan HMM meliputi tiga komponen yaitu hakikat manusia, dimensi kemanusiaan, dan pancadaya kemanusiaan.

Hakikat manusia itu merupakan inti dari kemanusiaan manusia. Keimanan dan ketakwaannya kepada Tuhan Yang Maha Esa merupakan hakikat manusia yang pertama. Untuk mengembangkan dirinya manusia dibekali dimensi-dimensi. Kelima dimensi kemanusiaan saling terkait. Dimensi kefitrahan menduduki posisi sentral yang mendasari keempat dimensi lainnya. Dimensi keindividualan, kesusilaan dan kesosialan saling terkait antara ketiganya, dan ketiganya itu terkait dengan dimensi kefitrahan dan keberagamaan; sedangkan dimensi keberagamaan merupakan bingkai dan sekaligus wajah dari keseluruhan aktualisasi kehidupan individu dengan kelima dimensinya itu.

Kata kunci kandungan dimensi keberagamaan adalah iman dan taqwa. Dalam dimensi ini terkandung pemahaman bahwa setiap individu pada dasarnya memiliki kecenderungan dan kemampuan untuk mempercayai adanya Sang Maha Pencipta dan Maha Kuasa serta mematuhi segenap aturan dan perintah-Nya. Keimanan dan ketaqwaan ini dibahas dalam agama yang dianut oleh setiap individu.

Pancadaya merupakan modal dasar bagi pengembangan kecerdasan individu. Daya taqwa adalah bagian dari panca daya yang pertama, artinya ketaqwaan merupakan basis dan kekuatan pengembangan yang secara hakiki ada pada diri manusia untuk mengimani dan mengikuti perintah dan larangan dari Allah SWT. Jika seseorang sudah bertaqwa maka hasil dari daya cipta, daya rasa, daya karsa dan daya karya semuanya bertujuan untuk mengharapkan redha Allah semata.

Pendidikan karakter ini harus dilakukan secara komprehensif dan integral, baik di sekolah, rumah maupun masyarakat. Berkenaan dengan proses pembelajaran, para pendidik pada satuan-satuan pendidikan dalam penyelenggaraan pembelajarannya dapat mengintegrasikan materi pendidikan karakter cerdas ke dalam materi pelajaran yang dibelajarkannya. Untuk melaksanakan hal tersebut, Lufri \& Festiyet (2011) menyatakan bahwa seorang pendidik harus memiliki syarat-syarat: (1) meneladani sifat Rasulullah, (2) memahami prinsip-prinsip keteladanan, yaitu dimulai dari diri sendiri, (3) mengetahui tahapan mendidik karakter. Sekurangkurangnya ada tiga tahapan pembelajaran karakter yaitu; (a) tahapan pemikiran, merupakan tahap memberikan pengetahuan tentang karakter, (b) tahap perasaan, merupakan tahap mencintai dan membutuhkan karakter positif, dan (c) tahapan perbuatan, pada tahap ini dorongan/keinginan yang kuat pada diri peserta didik untuk mempraktekkan karakter positif yang diwujudkan dalam kehidupan sehari-hari. 


\section{PENDIDIKAN BIOLOGI BER- BASIS IMTAQ UNTUK MEM- BANGUN KARAKTER BANGSA}

\section{Kedudukan Mata Pelajaran Biologi di Sekolah/Madrasah}

Permendiknas no 22 tahun 2006 tentang Standar Isi untuk satuan pendidikan dasar menengah menyatakan Biologi atau Ilmu Pengetahuan Alam (IPA) termasuk dalam kelompok mata pelajaran ilmu pengetahuan dan teknologi. IPA berkaitan dengan cara mencari tahu (inquiry) tentang alam secara sistematis, sehingga IPA bukan hanya sebagai penguasaan kumpulan pengetahuan yang berupa fakta-fakta, konsepkonsep atau prinsip-prinsip saja, tetapi juga merupakan suatu proses penemuan. Pendidikan IPA di sekolah menengah diharapkan dapat menjadi wahana nagi peserta didik untuk mempelajari diri sendiri dan alam sekitar, serta prospek pengembangan lebih lanjut dalam menerapkannya dalam kehidupan sehari-hari. Pendidikan IPA menekankan pada pemberian pengalaman langsung untuk mengembangkan kompetensi agar peserta didik menjelajahi dan memahami alam sekitar secara ilmiah. Pendidikan IPA diarahkan untuk mencari tahu dan berbuat sehingga dapat membantu peserta didik untuk memperoleh pemahaman yang lebih mendalam tentang dirinya sendiri dan alam sekitar.

Mata pelajaran Biologi bertujuan agar peserta didik memiliki kemampuan sebagai berikut: (1) Membentuk sikap positif terhadap biologi dengan menyadari keteraturan dan keindahan alam serta mengagungkan kebesaran Tuhan Yang Maha Esa, (2) Memupuk sikap ilmiah yaitu jujur, objektif, terbuka, ulet, kritis, dan dapat bekerja sama dengan orang lain, (3) Mengembangkan pengalaman untuk dapat mengajukan dan menguji hipotesis melalui percobaan, serta mengkomunikasikan hasil percobaan secara lisan dan tertulis, (4)
Mengembangkan kemampuan berpikir analitis, induktif, dan deduktif dengan meggunakan konsep dan prinsip biologi, (5) Mengembangkan penguasaan konsep dan prinsip biologi dan saling keterkaitannya dengan IPA lainnya serta mengembangkan pengetahuan ketrampilan dan sikap percaya diri, (6) Menerapkan konsep dan prinsip biologi untuk menghasilkan karya teknologi sederhana yang berkaitan dengan kebutuhan manusia, (7) meningkatkan kesadaran dan berperan serta dalam menjaga kelestarian lingkungan.

Fungsi dipelajarinya IPA/sains di sekolah/madrasah adalah untuk: (1) membangun pola pikir peserta didik, (2) membantu peserta didik menjelaskan adanya hubungan antara berbagai gejala alam, (3) meramalkan yang didasarkan pada konsistensi atau keteraturan dari gejala alam tersebut, (4) menguasai atau mengontrol alam guna kesejahteraan manusia, (5) melestarikan/merekam berbagai gejala alam, yang mungkin tidak akan terulang kembali kejadiannya. Berdasarkan hal tersebut nilai-nilai karakter yang terkandung dalam mata pelajaran biologi antara lain: religius, ingin tahu, senang membaca, peduli kesehatan, mandiri, kerja keras, toleransi, bersahabat/komunikatif, peduli sosial, tanggung jawa, peduli sosial. (Lufri \& Festiyet, 2009; Kemdiknas, 2010)

\section{Perspektif Islam dalam Mempelajari Biologi}

Manusia disuruh untuk mempelajari ciptaan Allah yang berhubungan dengan mahkluk/ benda hidup dengan ilmu pengetahuan, dan ilmu pengetahuan yang berhubungan dengan organisme atau benda hidup adalah biologi. Biologi merupakan ilmu pengetahuan (science) yang mempelajari tentang perihal kehidupan sejak berjuta tahun yang lalu hingga sekarang dengan perwujudan dan kompleksitasnya, dimulai dari sub-par- 
tikel atam hingga interaksi antar makhluk hidup dan bagaimana hubungannnya dengan lingkungannya (ekosistem).

Berikut ini beberapa alasan yang dikemukakan, tentang pentingnya mempelajari biologi;

a. Salah satu cabang ilmu pengetahuan yang diperlukan untuk menafsirkan ayat-ayat alqur'an yang berhubungan dengan makhluk hidup. Salah satu Firman Allah SWT yang meminta manusia memikirkan mahkluk hidup terdapat dalam Q.S. Al Ghasyiyah, 88: 17 menyatakan: Apakah mereka tidak memperhatikan Unta, bagaimana ia diciptakan?

b. Untuk mengetahui lebih banyak tentang diri manusia sendiri dan bumi yang dihuninya. Dengan mempelajari alam semesta (beserta isinya) membuat manusia mengetahui dan memahami kebesaran Allah serta makin bertakwa kepada-Nya. Sebagaima firman Allah SWT dalam Q.S. Fushilat ayat 53: "Akan Kami perlihatkan kepada mereka ayat-ayat Kami di segenap penjuru alam dan dalam diri mereka sendiri, sehingga jelaslah bagi mereka bahwa Al-Quran itulah yang benar'.

c. Manusia bisa menjawab masalahmasalah yang melibatkan prinsipprinsip biologi dan kesejahteraannya, seperti; penggunan makanan tambahan (aditif), obat, insektisida, penyinaran (radiasi), rekayasa genetika, dan cara-cara pengendalian populasi. Apakah halhal di atas membawa peningkatan atau penurunan terhadap nilai-nilai kehidupan kita, terutama yang berkaitan dengan halal dan haramnya sesuatu serta hikmah yang terdapat di dalamnya.

\section{Konsep Integrasi Imtaq dan Iptek dalam Mata Pelajaran Sains/ Biologi}

'Iptek' dan 'imtaq' merupakan dua istilah yang berasal dari singkatan 'ilmu pengetahuan dan teknologi' dan 'iman dan taqwa'. Istilah iptek merupakan perpaduan antara ilmu pengetahuan (sains) dan teknologi. Sains dan teknologi merupakan dua hal yang tidak terpisahkan, sains merupakan sumber teknologi dan teknologi merupakan aplikasi sains. Sains dapat diartikan sebagai himpunan rasional kolektif insan, tentang alam yang diperoleh melalui konsensus para pakar. Sedangkan teknologi adalah sebagai himpunan pengetahuan terapan manusia tentang prosesproses pemanfaatan alam yang diperoleh dari penerapan sains, dalam kegiatan yang produktis ekonomis (Baiquni, 1997: 63).

Istilah imtaq merupakan gambaran karakteristik nilai-nilai keagamaan (keislaman) yang harus dimiliki oleh setiap muslim. Imtaq merupakan urusan yang sarat dengan nilai, kepercayaan, pemahaman, sikap, perasaan dan perilaku yang bersumber dari al-Qur'an dan Hadist (Ahmad Sanusi dalam Syaifuddin, 2006: 35). Selanjutnya dikatakan, ajaran islam bukan semata-mata aspek teologi tetapi mencakup seluruh aspek kehidupan termasuk ilmu pengetahuan umum (selain agama), meskipun dilihat dari proses lahirnya sebagian bersifat ijtihad/hasil pemikiran manusia.

Islam tidak memandang ilmu agama (imtaq) dan ilmu umum (iptek) terpisah, karena keduanya berasal dari sumber yang satu, yaitu Allah swt. Pengetahuan dalam bentuk imtaq adalah pengetahuan yang bersumber langsung dari Allah swt, dalam bentuk wahyu yang diturunkan melalui Nabi Muhammad saw sebagai rasulnya. Sedangkan pengetahuan dalam bentuk iptek, pada dasarnya juga berasal dari 
Allah, yang didapat oleh manusia melalui alam, akal/nalar manusia yang diciptakan oleh Allah swt. Allah menghendaki hambanya selalu belajar, termasuk mempelajari alam. Seperdelapan ayat-ayat al Qur'an atau \pm 750 ayat adalah ayat-ayat kauniyah yaitu ayat-ayat yang berhubungan dengan gejala-gejala alam yang semuanya merangsang, menegur dan mendorong umat Islam untuk melakukan kegiatan yang menuju pada pengembangan sains.

Zainuddin Sardar (1996: 45) dan Syaifuddin Sabda (2006) mengemukakan tiga bentuk/cara mengintegrasi atau pemaduan iptek dan imtaq ini. 1). Dengan cara mengkonsultasikan konsep atau teori-teori iptek dengan paradigma dan prinsip-prinsip sains islami guna melahirkan sains yang islami; 2). Dengan cara menghubungkan teori dan konsep-konsep iptek dengan teori dan konsep imtaq; 3) dengan cara melakukan hubungan timbal balik dua arah.

Integrasi materi Imtaq dan Iptek di sekolah/madrasah salah satunya bisa pada mata pelajaran MIPA (Matematika dan Ilmu Pengetahuan Alam). Wardiman Djojonegoro cit Dedi Supriadi (2004 : 125) menyatakan bahwa pendidikan MIPA mengandung tiga aspek. Pertama, berkenaan dengan substansi ke-MIPA-an (science education). Melalui pendidikan MIPA peserta didik diarahkan untuk menguasai dalil-dalil, teori-teori, generalisasi-generalisasi, konsep-konsep, dan prinsip-prinsip MIPA untuk kemudian diterapkan dalam pemecahan masalah keilmuan. Kedua, MIPA merupakan alat (means) pendidikan yang lebih luas, yang dikenal dengan education through science. Melalui MIPA, logika berpikir peserta didik dikembangkan sehingga lebih tertib, lugas, dan sistematis. Ketiga, aspek nilai moral dan etik yang terkandung dalam pendidikan MIPA, melalui MIPA peserta didik dapat lebih mencintai lingkungan, sadar akan keuntungan MIPA bagi kehidupan manu- sia, dan sadar pula akan implikasi dari penerapan MIPA terhadap kehidupan manusia. Jika disalahgunakan untuk tujuan-tujuan yang destruktif seperti pembuatan bom nuklir, genetika, eksploitasi sumberdaya alam yang melebihi batas, akan menimbulkan kerusakan. Disamping itu, peserta didik dapat lebih memahami betapa agung dan perkasanya Allah yang menciptakan alam semesta ini dalam keadaan tertib, tidak kacau. Dalam al-Qur'an, misalnya, banyak kita temukan amsal-amsal yang baik secara eksplisit maupun implisit menjelaskan bagaimana alam semesta bersama isinya ini tunduk kepada hukum-hukum Allah, mulai dari perilaku lebah sampai kepada orbit planet di tata surya. Oleh sebab, itu, jika dikembalikan kepada dasarnya, MIPA sesungguhnya merupakan upaya untuk memahami hukum-hukum Allah (sunnatullah) yang juga disebut "hukum alam".

\section{Pendidikan Biologi Berbasis Imtaq/Nilai-Nilai Agama Islam Se- bagai Usaha Pembentukan Karakter Bangsa}

Pengintegrasikan imtaq pada materi pelajaran sains (Biologi) yang berbasis iptek merupakan bagian dari pemenuhan HMM. Seperti yang dinyatakan sebelumnya, pada hakikatnya manusia itu beriman dan bertaqwa, dalam dimensi kemanusiaan mengakui adanya keberagamaan dalam bentuk iman dan taqwa berdasarkan ajaran agama yang dianut. Jika seorang sudah bertaqwa maka ini menjadi potensi dasarnya kemanusiaanya yaitu daya taqwa, karena daya taqwa merupakan dasar dari aktivitas individu.

Hal ini juga sejalan dengan tujuan dari mata pelajaran Biologi yang pertama yaitu, membentuk sikap positif terhadap biologi dengan menyadari keteraturan dan keindahan alam serta mengagungkan kebesaran Tuhan Yang Maha Esa. Artinya, guru biologi juga 
bertanggung jawab dalam menamamkan nilai-nilai Islam/imtaq dalam materi yang diajarkannya, sehingga tujuan pembelajaran biologi bisa tercapai.

Tujuan pendidikan nasional adalah membentuk manusia yang berakhlak mulia/punya karakter, artinya semua guru bertanggungjawab untuk mencapai tujuan tersebut termasuk guru biologi. Maka dalam setiap kegiatan pembelajaran/pendidikan yang dilaksanakannya guru biologi adalah (1) guru yang menjadi teladan bagi peserta didiknya, (2) guru yang bertanggungjawab terhadap pembentukan karakter/ akhlak peserta didiknya, dan (3) guru yang bisa mengintegrasikan aspek iptek dan imtaq dalam kegiatan pembelajarannya.

Sebagai contoh materi yang mengintegrasikan konsep imtaq pada pokok bahasan biologi adalah tentang sel. Kerumitan dan kesempurnaan penciptaan sel baik dari segi struktur maupun fungsinya tidak bisa di kalahkan oleh teknologi muhktahir sekalipun. Begitu teraturnya susunan sel pada mahkluk hidup mulai dari tingkat uniseluler hingga multi seluler dengan kerumitan sistem organnya akan membuat orang sadar ada yang "menciptakan". Maha pencipta yang mengatur segalanya tanpa perlu bantuan dari manusia. Kesadaran akan "ada yang menciptakan" yang Maha Melihat dan Maha mengetahui membuat peserta didik merasa setiap tindak tanduknya ada yang mengawasi. Pemahaman seperti ini menyentuh aspek hakikat manusia, dimensi kemanusiaan dan potensi dasar manusia dalam wujud panca daya.

Pengembangan komponen ketakwaan dalam HMM secara tepat, berhasil dan optimal akan membawa individu menjadi orang-orang yang beriman dan bertakwa kepada Tuhan Yang Maha Esa. Dengan memupuk ketaqwaannya, maka segala aktivitas peserta didik; berpikir, merasa, bersikap, bertindak dan bertanggung jawab (BMB3) akan dilandasi oleh nilai-nilai ketaqwaan. Menjadikan BMB3 sebagai dasar segala aktivitas akan melahirkan/membentuk peserta didik yang berkarakter (berakhlak mulia) yang tergambar dalam penampilannya sehari-hari.

\section{PELAKSANAAN DAN KENDALA PENDIDIKAN BERBASIS IMTAQ DI SEKOLAH}

Integrasi pendidikan imtaq sebagai wujud pendidikan karakter dalam perencanaan pembelajaran merupakan upaya awal dalam menanamkan nilainilai akhlak dalam kegiatan pembelajaran. Upaya ini harus ditindaklanjuti dengan kegiatan pelaksanaan pembelajaran yang memungkinkan tercapainya keterpaduan antara penyajian materi dengan nilai-nilai karakter. Oleh karena itu, dalam integrasi ini harus dititikberatkan pada aspek sikap dan perilaku, kemudian aspek kognitif. Tujuannya adalah terbentuknya sosok peserta didik yang memiliki karakter dan kepribadian yang dilandasi dengan keimanan dan ketakwaan serta nilai-nilai akhlak yang kokoh yang tercermin dalam keseluruhan sikap dan perilaku seharihari.

Pembentukan sikap dan perilaku yang terpuji memerlukan bentuk pembelajaran yang mampu memberikan peluang penghayatan atau internalisasi nilai. Berbeda dengan transformasi ilmu pengetahuan yang dapat dilakukan seketika dan sewaktu-waktu, penghayatan atau internalisasi nilai merupakan proses yang memerlukan pengulangan dan kesinambungan. Untuk itu, dalam proses pembelajaran harus memadukan antara penyajian materi dan penerapan nilainilai akhlak yang terpuji dalam kehidupan sehari-hari. Dalam hal penilaian 
mengenai akhlak (karakter) anak didik dapat dilakukan guru atau dosen melalui alat penilaian non tes seperti wawancara, pengamatan, skala sikap, dan lain-lain yang memungkinkan guru mendapatkan informasi yang sebanyak-banyaknya dari pihak-pihak yang mempunyai kepentingan dan kepedulian terhadap proses pendidikan.

Namun pembelajaran yang mengintegrasikan iptek dan imtaq ini juga mempunyai kendala-kendala. Agus W.D. (2010: 4) menyatakan kendala dalam pelaksanannya adalah: (1) dari guru, guru harus mempunyai kemampuan mengkaitkannya nilai-nilai agama dari materi pelajarannya dengan ayatayat Al-Qur'an. Dan ada anggapan guru, mengintegrasikan nilai-nilai agama dengan materi pelajarannya hanya menambah beban tugasnya saja, (2). Nilainilai agama yang diajarkan ini tidak dimasukkan ke dalam soal evaluasi. Disamping itu, (3). Kelengkapan sarana pendidikan juga menentukan. Inovasi model pembelajaran dan pemakaian media akan sulit berkembang atau terlaksana dengan baik bila tidak didukung oleh sarana dan prasarana pendidikan yang memadai.

Kendala lain pendidikan berbasis Imtaq di sekolah adalah paradigma guru dalam mengukur keberhasilan siswa masih banyak yang menitikberatkan pada aspek kognitif saja, sementara aspek afektif dan psikomotorik masih banyak yang dikesampingkan. Di samping itu juga belum siapnya guru atau dosen secara keseluruhan untuk memberikan keteladanan sikap dan perilaku kepada anak didiknya, karena dalam kenyataannya selama ini, guru atau dosen kalau sudah selesai mengajar berarti selesai pula tugasnya, padahal masih ada tugas yang lebih substansial yaitu mendidik melalui keteladanan sikap dan perilaku yang diwujudkan dalam bertutur kata, bersikap, dan bertindak.
Sedangkan kelemahannya menurut sebagian orang adalah bahwa di era global segala sesuatu tidak terikat dengan masalah moral (akhlak). Menurutnya, Ilmu pengetahuan mempunyai sifat bebas nilai, sehingga dalam pengembangannya pun termasuk untuk mencapai keunggulan komparatif dalam bidang Ipteks akan terhambat kalau masih dikaitkan dengan masalah akhlak (moral agama). Namun demikian, pengembangan ilmu pengetahuan dan teknologi tetap harus dilandasi dengan imtaq, sehingga tidak akan terjadi kesenjangan antara idealitas moral dan realitas ilmu pengetahuan.

\section{PENUTUP}

Tujuan pendidikan adalah memuliakan kemanusian manusia. Hasil dari kegiatan pendidikan adalah manusia yang terdidik, yaitu yang dapat menggunakan ilmunya untuk hal-hal yang baik (beramal shaleh), dan dapat hidup secara bijak dalam seluruh aspek kehidupan berkeluarga, bertetangga, bermasyarakat, dan bernegara. Tujuan pendidikan tersebut akan tercapai jika dilaksanakan dalam suatu kerangka situasi pendidikan, dimana terjadi interaksi antara pendidik dan peserta didik dalam proses pembelajaran. Proses itu dipengaruhi oleh dua pilar utama pendidikan yaitu, kewibawaan dan kewiyataan. Kewibawaan melekat sebagai kepribadian/karakter guru dan kewiyataan merupakan ketrampilan guru dalam mengajar. Kedua pilar tersebut merupakan dasar bagi seorang guru untuk melaksanakan tugasnya sebagai pendidik dan pengajar yang berlandaskan ilmu pendidikan.

Dalam melaksanakan tugasnya seorang guru harus mengacu kepada tujuan pendidikan yang sudah ditetapkan. Tujuan pendidikan nasional adalah membentuk manusia yang berakhlak mulia/punya karakter cerdas, artinya 
semua guru bertanggungjawab untuk mencapai tujuan tersebut termasuk guru biologi. Maka dalam setiap kegiatan pembelajaran/pendidikan yang dilaksanakan guru biologi adalah (1) guru yang menjadi teladan bagi peserta didiknya, (2) guru yang bertanggungjawab terhadap pembentukan karakter/ akhlak

\section{DAFTAR RUJUKAN}

Agus Waskito Dwi, 2010. Pembelajaran Biologi yang Berbasis Imtaq dengan Pendekatan Integratif (Science, Environment, Society, Teknology and Religion). (Online)

Ahmad Baiquni, 1997. Al-Qur'an dan Ilmu Pengetahuan Kealaman. Dana Bhakti Primayasa. Yogyakarta.

Asep Nur Zaman. 2003. Pendidikan Islam Keluar dari Suasana Kolot. Koran Republika. Senin 6 Januari 2003.

Dedi Supriadi. 2004. Membangun Bangsa Melalui Pendidikan. Remaja Rosda Karya. Bandung.

Harun Yahya, 2002. Bacalah dengan Nama Tuhanmu Yang Menciptakan. Pengantar Film Pengetahuan Populer Harun Yahya Series. Jakarta: Nada Cipta Raya.

Lufri \& Festiyet. 2011. Pengintegrasian dan Keterkaitan Pendidikan Berkarakter dalam Pembelajaran MIPA. Makalah, disampaikan dalam Seminar Nasional "integrasi Pendidikan Berkarakter dalam Kurikulum MIPA dan Pendidikan MIPA" UNP Padang. 19-20 November 2011.

Kemdiknas. 2010. Panduan Guru Mata Pelajaran, Pendidikan Karakter peserta didiknya, dan (3) guru yang bisa mengintegrasikan aspek iptek dan imtaq dalam kegiatan pembelajarannya. Dasar dari pendidikan adalah HMM, dan HMM yang tidak mengenal adanya dikotomi antara ilmu pengetahuan dan agama karena semua ilmu itu datangnya dari Allah SWT semata.

Terintegrasi dalam Pembelajaran di Sekolah Menengah Pertama. Jakarta: Kemdiknas.

Thomas Lickona (1992), Eleven Principles Of Effective Character Education. CEP website: www.character.org diakses 20 November 2011.

Permendiknas Nomor 22 tahun 2006. tentang Standar Isi untuk Satuan Pendidikan Dasar dan Menengah. Sekretariat Jendral Depdiknas.

Prayitno, 2009. Dasar Teori dan Praksis Pendidikan. Jakarta: Grasindo.

\& Belferik Manullang. 2010. Pendidikan Karakter dalam Pembengunan Bangsa. Medan: Unimed.

\& Afriva Khaidir. 2011. Model Pendidikan Karakter. Padang: UNP Press.

Syaifuddin Sabda. 2006. Model Kurikulum Terpadu Iptek dan Imtaq, Desain, Pengembangan dan Implementasi. Quantum Teaching. Jakarta.

Zainuddin Sardar (1996). Jihad intelektual, Merumuskan ParamiterParamiter Sains Islam, Terjemahan AE Priyono, Risalah Gusti, Surabaya. 
